\title{
Norfluoxetine Enantiomers as Inhibitors of Serotonin Uptake in Rat Brain
}

Droid T. Wong, Ph.D., Frank P. Bymaster, M.S., Leroy R. Reid, B.S., Douglas A. Mayle, B.S., meph H. Krushinski, M.S., and David W. Robertson, Ph.D.

L' fiuoxetine, the $N$-demethylated metabolite moxetine exists in $R$ - and S-enantiomeric forms. SNorfluoxetine inhibited serotonin (5-HT) uptake and PHIparoxetine binding to 5-HT uptake sites with a $p K_{i}$ of 7.86 and 8.88 or 14 and $1.3 n M$, respectively, whereas R-morfuoxetine was 22 and 20 times, respectively, less mont. R-and S-Norfluoxetine were less potent than the onesponding enantiomers of fluoxetine as inhibitors of mepinephrine uptake and $\left[{ }^{3} \mathrm{H}\right]$ tomoxetine binding to mepinephrine uptake sites. Ex vivo studies showed that Snorfluoxetine inhibited 5-HT uptake with an $E D_{50}$ of 3 mogg intraperitoneally, $4.7 \mathrm{mg} / \mathrm{kg}$ subcutaneously, and
$9 \mathrm{mg} / \mathrm{kg}$ orally $(7.3,11.4$ and $21.9 \mu \mathrm{mol} / \mathrm{kg}$, respectively), while the $E D_{50}$ for $R$-norfluoxetine exceeded $20 \mathrm{mg} / \mathrm{kg}$ intraperitoneally $(48.6 \mu \mathrm{mol} / \mathrm{kg})$. Inhibition of 5-HT uptake in cerebral cortex ex vivo and decrease in 5-HIAA levels in hypothalamus persisted for 24 hours after administration of S-norfluoxetine as demonstrated with the administration of fluoxetine. Thus, $\mathrm{S}$-norfluoxetine is the active $\mathrm{N}$-demethylated metabolite responsible for the persistently potent and selective inhibition of 5-HT uptake in vivo.

[Neuropsychopharmacology 8:337-344, 1993]
Ir woRDs: Fluoxetine; Norfluoxetine; Enantiomers; Srotonin 5-HT; Uptake; Inhibitors

Awoxetine, a selective inhibitor of serotonin (5-hydroxyyptamine, 5-HT) uptake (Wong et al., 1974, 1975), has wen successfully developed as an antidepressant drug (Feighner 1983; Beasley et al. 1990). Fluoxetine is dereloped and is marketed as the racemate, i.e., the $R$ $(-)$ and $S(+)$ enantiomers of equal amounts. Both ontiomers inhibit 5-HT uptake and effectively produce functional responses associated with an increased S-HT transmission. There are no major differences in potency between $R$ - and $S$-fluoxetine, and their eudismic ratio is close to unity (Wong et al., 1985, 1990;

\footnotetext{
from the Lilly Research Laboratories, Eli Lilly and Company, Lilly Copporate Center, Indianapolis, Indiana 46285.

Address correspondence to: David T. Wong, Ph.D., Lilly Research Loratories, Eli Lilly and Company, Lilly Corporate Center, InEmpolis, Indiana 46285.

Received May 8, 1992; revised November 6, 1992; accepted Norember 15, 1992.
}

Robertson et al. 1988). Enzymatic N-demethylation is an early step of fluoxetine metabolism, and the demethylated compound norfluoxetine (Fig. 1) is a major metabolite (Parli and Hicks 1974; Lemberger et al. 1978; Beasley et al. 1990) in laboratory animals and in man. Norfluoxetine is also a potent and selective inhibitor of 5-HT uptake (Wong et al. 1975; Horng and Wong 1976; Fuller et al. 1978). In the present communication, we report the pharmacologic profiles of $R$ - and $S$-norfluoxetine, which have been recently synthesized in high enantiomeric purity. In contrast with the two enantiomers of fluoxetine, however, we have found that $S$-norfluoxetine is over 20 -fold more potent than the $R$ enantiomer as an inhibitor of 5-HT uptake both in vitro and in vivo.

\section{MATERIALS AND METHODS}

Male Sprague-Dawley rats weighing between 100 and $150 \mathrm{~g}$ (Harlan Industries, Cumberland, IN) were housed in a room with a 12 -hour dark/light cycle at $23^{\circ} \mathrm{C}$, and 


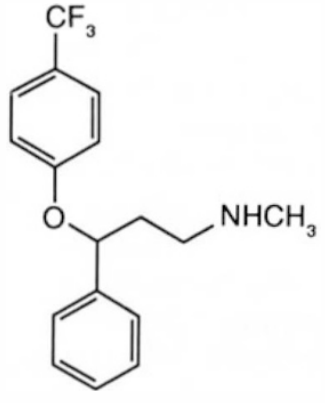

Fluoxetine

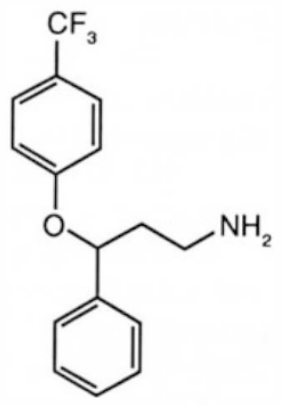

Norfluoxetine
Figure 1. Chemical structures of fluoxetine and norfluoxetine.

had free access to Purina Chow pellets and water. Rats were killed by decapitation. Brain tissues of cerebral cortex, hypothalamus, or striatum were homogenized in 9 volumes of a medium containing $0.32 \mathrm{~mol} / \mathrm{L}$ sucrose and $10 \mathrm{mmol} / \mathrm{L}$ glucose. Crude synaptosomal preparations were isolated after differential centrifugation at $1000 \times g$ for 10 minutes and $17,000 \times g$ for 28 minutes. The final pellets were suspended in the same medium and kept on ice until used within the same day.

Synaptosomal uptake of tritium-labeled 5-HT, norepinephrine (NE), or dopamine (DA) was determined as follows: synaptosomal preparations (equivalent to 0.5 to $1.0 \mathrm{mg}$ of protein) were incubated at $37^{\circ} \mathrm{C}$ for 5 minutes in $1 \mathrm{ml}$ of Krebs bicarbonate medium containing also $10 \mathrm{mmol} / \mathrm{L}$ glucose, $0.1 \mathrm{mmol} / \mathrm{L}$ iproniazid, 1 $\mathrm{mmol} / \mathrm{L}$ ascorbic acid, $0.17 \mathrm{mmol} / \mathrm{L}$ EDTA, and $\left[{ }^{3} \mathrm{H}\right]-$ monoamine at a specified concentration. The reaction mixture was immediately diluted with $2 \mathrm{ml}$ of $0.9 \%$ saline and filtered using Whatman GF/B filters under vacuum with a cell harvester (Brandel, Gaithersburg, MD). Filters were rinsed twice with approximately 5 $\mathrm{ml}$ of ice-chilled $0.9 \%$ saline and were transferred to a counting vial containing $10 \mathrm{ml}$ of scintillation fluid (PCS; Amersham, Arlington Heights, IL.). Radioactivity was measured by a liquid scintillation spectrophotometer. Accumulation of activity at $4^{\circ} \mathrm{C}$ represented the background and was subtracted from all samples. Uptake of 5-HT in human platelets was conducted according to previously described methods (Horng and Wong 1976; Lemberger et al. 1978).

Radioligand-binding assays were conducted according to previously described methods. Briefly, synaptosomal preparations of rat cerebral cortex, bovine choroid plexus, or striatum were suspended by homogenizing in 50 volumes of cold reaction medium (50 $\mathrm{mmol} / \mathrm{L}$ Tris- $\mathrm{HCl}, \mathrm{pH} 7.4$, with or without $150 \mathrm{mmol} / \mathrm{L}$ $\mathrm{NaCl}, 50 \mathrm{mmol} / \mathrm{L} \mathrm{KCl}$ ) and centrifuging at 50,000 $\times g$ for 10 minutes. The process was repeated two times with a 10 -minute incubation at $37^{\circ} \mathrm{C}$ between the sec ond and third washes. The final pellet was stored a $-70^{\circ} \mathrm{C}$ until use.

Binding of $\left[{ }^{3} \mathrm{H}\right]$ paroxetine to $5-\mathrm{HT}$ uptake sites wæ carried out in $2 \mathrm{ml}$ of reaction medium containing the appropriate drug concentrations, $0.1 \mathrm{nmol} /\left.\mathrm{kg}\right|^{3} \mathrm{HF}$ paroxetine and the cerebral cortical membranes (equivz lent to $50 \mu \mathrm{g}$ protein/tube) (Marcusson et al. 1988), and $\left[{ }^{3} \mathrm{H}\right.$ ] tomoxetine at $0.2 \mathrm{nmol} / \mathrm{kg}$ was used to label $\mathrm{NE}$ uptake sites using a higher concentration of $300 \mathrm{mmol}$ $\mathrm{kg} \mathrm{NaCl}$ as previously described (Wong et al. 1991). Samples were incubated at $37^{\circ} \mathrm{C}$ for 30 minutes, and those containing $1 \mu \mathrm{mol} / \mathrm{kg}$ fluoxetine or desipramine were used to determine nonspecific binding of ${ }^{3} \mathrm{H} /$ paroxetine and $\left[{ }^{3} \mathrm{H}\right]$ tomoxetine, respectively. After incubation, the tubes were filtered through Whatman GF/B filters, which were soaked in $0.05 \%$ polyethylenmine for 1 hour before use, using a cell harvester by

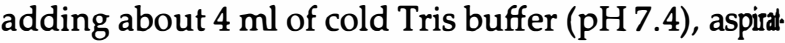
ing, and rinsing the tubes three additional times. Filles were then placed in scintillation vials containing $10 \mathrm{ml}$ of scintillation fluid, and the radioactivity was measured by liquid scintillation spectrophotometry. Radioligandbinding assays for subrypes of receptors of 5-HT and other neurotransmitters were conducted accordingt previously described methods (Hoyer 1985; Wong t al. 1983, 1989, 1991b).

For in vivo studies, rats were fasted overnight prior to oral administration of drugs. Groups of five rats wer given drugs by specified routes and doses, and wer killed by decapitation at appropriate times. Brain arex were quickly dissected and placed either in cold 0.32 $\mathrm{mol} / \mathrm{L}$ sucrose medium for uptake studies, or werefrozen on dry ice for metabolite level determinations.

For measurement of 5-hydroxyindoleacetic adid (5-HIAA), brain tissues were homogenized in 5 to 10 volumes of $0.1 \mathrm{~N}$ trichloroacetic acid containing internal standard (5-hydroxyindolecarboxylic acid) and certrifuged at $10,000 \times g$ for 10 minutes. The 5-HIAA in $20 \mu \mathrm{l}$ of supernatant was determined by high-pressure liquid chromatography and electrochemical detection.

Enantiomers of fluoxetine and norfluoxetine were synthesized in the Lilly Research Laboratories (Indianapolis, IN). Serotonin $\left[1,2-{ }^{3} \mathrm{H}(\mathrm{N})\right](28.7 \mathrm{Ci} / \mathrm{mmol}) ;$ $1-\mathrm{NE}\left[8-{ }^{3} \mathrm{H}\right](57 \mathrm{Ci} / \mathrm{mmol}) ; \mathrm{DA}\left[7-{ }^{3} \mathrm{H}(\mathrm{N})\right](26.8 \mathrm{Ci} / \mathrm{mmol}) ;$ [phenyl-6- ${ }^{3} \mathrm{H}$ ]paroxetine $(25 \mathrm{Ci} / \mathrm{mmol}) ;$ [ $\mathrm{N}$-methyt ${ }^{3} \mathrm{H}$ ] tomoxetine $(80.3 \mathrm{Ci} / \mathrm{mmol})$; [propyl-2,3-ring 1,2,3 $\left.{ }^{3} \mathrm{H}\right] 8-O H D P A T(169.9 \mathrm{Ci} / \mathrm{mmol})$; [ethylene- ${ }^{3} \mathrm{H}$ ] ketanserin $(64.9 \mathrm{Ci} / \mathrm{mmol})$; [benzene-ring- ${ }^{3} \mathrm{H}$ ] spiperone $(23.3$ $\mathrm{Ci} / \mathrm{mmol})$; [pyridinyl-5- ${ }^{3} \mathrm{H}$ ]pyrilamine $(27.3 \mathrm{Ci} / \mathrm{mmol}) ;$ $\left[( \pm)\right.$ benzilic- $4^{\prime}{ }^{3} \mathrm{H}(\mathrm{N})$ quinuclidinyl benzilate, QNB $(33.1$ $\mathrm{Ci} / \mathrm{mmol}$ ); 2-[phenyoxy-3- $\left.{ }^{3} \mathrm{H}(\mathrm{N})\right]-W B 4101$ (24 Cil $\mathrm{mmol}) ;\left[4^{3} \mathrm{H}\right]$ clonidine $(22.2 \mathrm{Ci} / \mathrm{mmol})$; and levo-[propyl-1,2,3- $\left.{ }^{3} \mathrm{H}\right]$ dihydroalprenolol $(42.3 \mathrm{Ci} / \mathrm{mmol})$ were purchased from New England Nuclear (Boston, MA). N-6[Methyl- $\left.{ }^{3} \mathrm{H}\right]$ mesulergine $(84 \mathrm{Ci} / \mathrm{mmol})$ and 


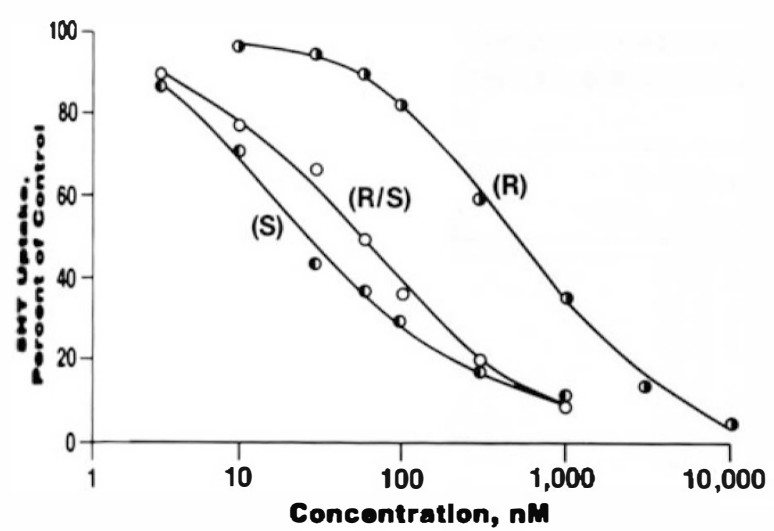

frume. Inhibition of 5-HT uptake in synaptosomal prepaion of rat cerebral cortex by norfluoxetine and its $R$ and Sorantiomers. Cortical synaptosomes equivalent to $1 \mathrm{mg}$ pro(in triplicate samples) were incubated at $37^{\circ} \mathrm{C}$ for 3 inutes in Krebs bicarbonate medium containing $50 \mathrm{nmol} / \mathrm{L}$ PAf $\mathrm{HT}, 10 \mathrm{mmol} / \mathrm{L}$ glucose, $0.1 \mathrm{mmol} / \mathrm{L}$ iproniazid, 0.2 $\mathrm{ofm}$ ascorbic acid, $0.2 \mathrm{mmol} / \mathrm{L}$ EDTA, and concentrations dtrugs as indicated. Other conditions were as described in Mnials and Methods

N-methyl- ${ }^{-3}$ H-LY278584 $(83.3 \mathrm{Ci} / \mathrm{mmol})$ were prepred by Amersham (Arlington Heights, IL).

Statistical analysis was conducted by the use of Student's t-test to compare means of control and drugtrated samples. A probability of less than 0.05 was reprded as significant.

\section{RESULTS}

S-Norfluoxetine inhibits 5-HT uptake in synaptosomal preparations isolated from rat cerebral cortex with inceasing concentrations from $3 \mathrm{nmol} / \mathrm{kg}$, whereas R-norfluoxetine exerted its inhibitory effect at much igher concentrations beginning at about $100 \mathrm{nmol} / \mathrm{kg}$, and as expected, the racemic mixture $R / S$-norfluoxetine had an intermediate potency (Fig. 2). From multiple de-

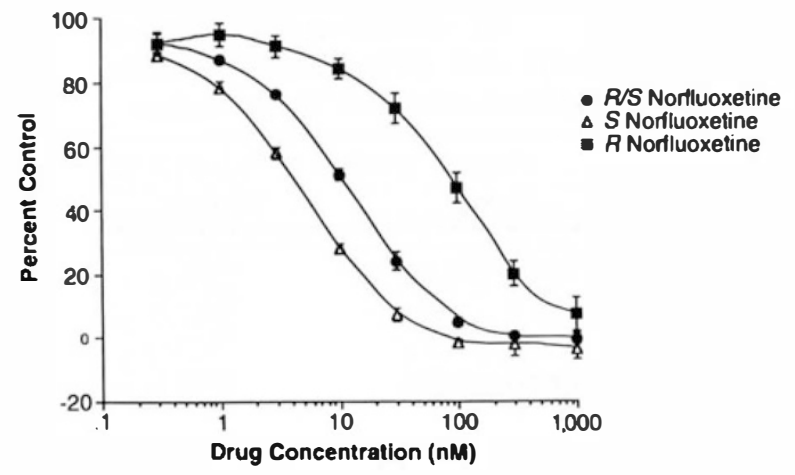

Figure 3. Inhibition of $\left[{ }^{3} \mathrm{H}\right]$ paroxetine binding in cortical membranes by norfluoxetine and its $R$ and $S$ enantiomers. Cortical membranes equivalent to $50 \mu \mathrm{g}$ of protein were incubated at $37^{\circ} \mathrm{C}$ for 30 minutes in $2 \mathrm{ml}$ of reaction medium containing the appropriate drug concentrations, $0.1 \mathrm{nmol} / \mathrm{L}$ $\left[{ }^{3} \mathrm{H}\right]$ paroxetine, $50 \mathrm{mmol} / \mathrm{L}$ Tris- $\mathrm{HCl}, \mathrm{pH} 7.4,150 \mathrm{mmol} / \mathrm{L}$ $\mathrm{NaCl}$, and $5 \mathrm{mmol} / \mathrm{L} \mathrm{KCl}$. Fluoxetine at $1 \mu \mathrm{mol} / \mathrm{kg}$ was used to determine nonspecific binding. Other conditions were as described in Materials and Methods.

terminations, the inhibitor constant ( $\mathrm{K}_{\mathrm{i}}$ values) were calculated from $\mathrm{IC}_{50}$ values (Cheng and Prusoff 1973) and are presented as $\mathrm{pK}_{\mathrm{i}}\left(-\log \mathrm{K}_{\mathrm{i}}, \mathrm{M}\right)$ values in Table 1. The mean $\mathrm{pK}_{\mathrm{i}}$ for $S$-norfluoxetine of $7.86 \pm 0.11$ is significantly higher than the $\mathrm{pK}_{\mathrm{i}}$ values for $R$-norfluoxetine and the racemate, indicating that the $S$ enantiomer is significantly more potent. Contrary to these findings, the two enantiomers and the racemic mixture fluoxetine inhibited 5-HT uptake with almost equipotency (Table 1) as previously reported (Wong et al. 1985, 1990).

Consistent with its potency as an inhibitor of 5-HT uptake, $S$-norfluoxetine was more potent than the racemate or $R$-norfluoxetine as an inhibitor of $\left[{ }^{3} \mathrm{H}\right]$ paroxetine binding to 5-HT uptake sites in cortical membranes (Fig. 3). The three compounds inhibited $\left[{ }^{3} \mathrm{H}\right]$ paroxetine binding with mean $\mathrm{pK}_{\mathrm{i}}$ values of $8.80 \pm 0.04,8.40$ \pm 0.04 , and $7.49 \pm 0.12$, respectively (Table 2 ). In agreement with the inhibition of $\left[{ }^{3} \mathrm{H}\right]$ fluoxetine binding

Table 1. Inhibition of 5-HT, NE, or DA Uptake in Synaptosomal Preparations by Enantiomers of Norfluoxetine and Fluoxetine

\begin{tabular}{lccc}
\hline \multicolumn{3}{c}{ Enantiomer } & \multicolumn{3}{c}{$\begin{array}{c}\text { Inhibition of Monoamine Uptake } \\
\left(\mathbf{p K i}\left(-\log \mathbf{K}_{\mathbf{i}}, \mathbf{M}\right)\right)\end{array}$} \\
\cline { 2 - 4 }$R / S$-Norfluoxetine & $\mathbf{5 - H T}$ & $\mathbf{N E}$ & $\mathbf{D A}$ \\
R-Norfluoxetine & $6.51 \pm 0.07$ & $5.62 \pm 0.14$ & $5.66 \pm 0.05$ \\
S-Norfluoxetine & $7.86 \pm 0.11^{b, *}$ & $5.43 \pm 0.15$ & $5.67 \pm 0.03$ \\
R/S-Fluoxetine & $7.69 \pm 0.04$ & $5.37 \pm 0.14$ & $5.56 \pm 0.03$ \\
$R$-Fluoxetine & $7.46 \pm 0.06$ & $5.91 \pm 0.12$ & $5.54 \pm 0.02$ \\
S-Fluoxetine & $7.66 \pm 0.05$ & $6.25 \pm 0.22$ & $5.55 \pm 0.02$ \\
\hline
\end{tabular}

Significant difference from racemate: ${ }^{a} p<.001 ;{ }^{b} p<.01$.

Significant difference between two enantiomers: ${ }^{\star} p<.001$. 
Table 2. Inhibition of $\left[{ }^{3} \mathrm{H}\right]$ Paroxetine and $\left[{ }^{3} \mathrm{H}\right]$ Tomoxetine Binding to Respective 5-HT and NE Uptake Carriers in Rat Cortical Membranes by Enantiomers of Fluoxetine and Norfluoxetine

\begin{tabular}{lccc}
\hline \multicolumn{1}{c}{ Drug } & Isomer & $\begin{array}{c}{\left[{ }^{3} \mathbf{H}\right] \text { Paroxetine }} \\
\left(\mathbf{p} \mathbf{K}_{\mathbf{i}}\left(-\log \mathbf{K}_{\mathbf{i}}, \mathbf{M}\right)\right)\end{array}$ & $\begin{array}{c}{\left[{ }^{3} \mathbf{H}\right] \text { Tomoxetine }} \\
\left(\mathbf{p K} \mathbf{i}_{\mathbf{i}}\left(-\log \mathbf{K}_{\mathbf{i}}, \mathbf{M}\right)\right)\end{array}$ \\
\hline Fluoxetine & $R / S$ & $8.51 \pm 0.03$ & $6.88 \pm 0.15$ \\
& $R$ & $8.46 \pm 0.02$ & $7.08 \pm 0.16$ \\
Norfluoxetine & $S$ & $8.53 \pm 0.01$ & $6.34 \pm 0.15$ \\
& $R / S$ & $8.48 \pm 0.04$ & $5.84 \pm 0.20$ \\
& $R$ & $7.58 \pm 0.12$ & $5.91 \pm 0.13$ \\
& $S$ & $8.88 \pm 0.04$ & $5.82 \pm 0.09$ \\
\hline
\end{tabular}

$\mathrm{pK}_{\mathrm{i}}$ presented as means $\pm \mathrm{SE}$ were calculated from $\mathrm{IC}_{50}$ values of at least three separate determinations.

(Wong et al. 1985), fluoxetine and its enantiomers are also potent inhibitors of $\left[{ }^{3} \mathrm{H}\right]$ paroxetine binding to 5-HT uptake carriers (Table 2).

Uptake of 5-HT in platelets of human and rat plasma is known to be inhibited by fluoxetine and norfluoxetine (Horng and Wong 1976). S-Norfluoxetine inhibited 5-HT uptake in human platelets with increasing concentrations (Fig. 4), and its $\mathrm{IC}_{50}$ value was $7.5 \mathrm{nmol} / \mathrm{kg}$; $S$-norfluoxetine was 2 and 14 times more potent than the racemate or the $R$ enantiomer, respectively.

Like fluoxetine, norfluoxetine and its two enantiomers were weak inhibitors of NE uptake in synaptosomal preparations (Table 1). S-Norfluoxetine had the lowest $\mathrm{pK}_{\mathrm{i}}$ of $5.23 \pm 0.04$, suggesting it is the least potent inhibitor of NE uptake among enantiomers of norfluoxetine and fluoxetine. Likewise, the two pairs of enantiomers are also weak inhibitors of DA uptake in striatal synaptosomes as previously reported for fluoxetine and norfluoxetine (Wong et al. 1990).

Consistent with being weak inhibitors of NE uptake, norfluoxetine and its enantiomers inhibited $\left[{ }^{3} \mathrm{H}\right]$ tomoxetine binding to NE uptake carriers (Wong et al. 1991a) with $p K_{i}$ values below 6, i.e., greater than micromolar concentrations (Table 2). Fluoxetine and its enantiomers were also weak inhibitors of $\left[{ }^{3} \mathrm{H}\right]$ tomoxetine binding.

The abilities of $R$ - and $S$-norfluoxetine to reduce 5 -HT uptake ex vivo were compared (Table 3 ). $S$-Norfluoxetine, upon administration to rats at 3,10 , and 20 $\mathrm{mg} / \mathrm{kg}(7.3,24.3$, and $48.6 \mu \mathrm{mol} / \mathrm{kg}$, respectively) by either intraperitoneal or subcutaneous routes, signifcantly lowered 5-HT uptake in hypothalamus homogenates, with estimated $\mathrm{ED}_{50}$ values of $3 \mathrm{mg} / \mathrm{kg}$ IP and $4.7 \mathrm{mg} / \mathrm{kg} \mathrm{SC}$. $R$-Norfluoxetine lowered 5-HT uptake at all three doses administered, but the $\mathrm{ED}_{50}$ values exceeded $20 \mathrm{mg} / \mathrm{kg}$ by either route of administration.

$S$-Norfluoxetine administered orally at 3,10 , and $20 \mathrm{mg} / \mathrm{kg}$ to rats also effectively reduced 5-HT uptake in hypothalamus homogenates with an $\mathrm{ED}_{50}$ of approximately $9 \mathrm{mg} / \mathrm{kg}$ po an hour after its administra- tion; the uptake of NE in the same tissue preparations remained unchanged (Table 4). In the same groups of rats, indole metabolites (5-HT and 5-HIAA) in cerebral cortex were measured, and 5-HT levels were essentially unchanged after treatment with the three doses of $S$-norfluoxetine; however, 5-HIAA levels were lower than control and this decrease in 5-HIAA levels became statistically significant at the $20-\mathrm{mg} / \mathrm{kg}$ dose (Table 4).

The duration of lowering of 5-HT uptake after a single oral administration of $S$-norfluoxetine at $20 \mathrm{mg} / \mathrm{kg}$ was found to be comparable to that caused by a similar treatment with fluoxetine and S-fluoxetine (Wong et al. $1975,1985)$. Within an hour of treatment, 5-HT uptake in homogenates of cerebral cortex was reduced to be low $30 \%$ of control activity, and the decrease persisted for 24 hours. Levels of 5-HIAA in hypothalamus were also significantly reduced at each time period of treat-

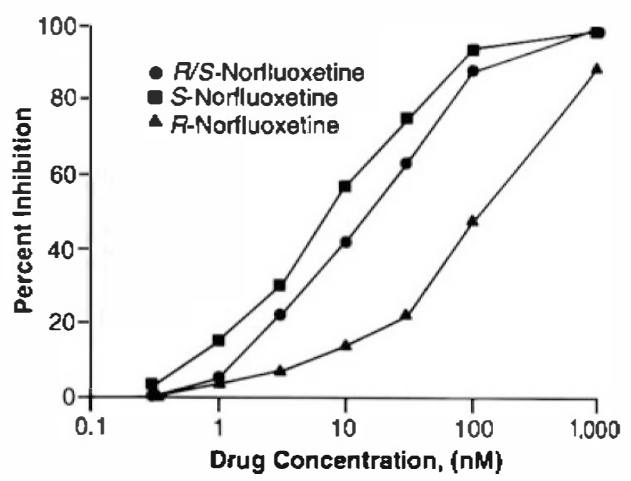

Figure 4. Inhibition of 5-HT uptake in human platelets by norfluoxetine and its $R$ and $S$ enantiomers. Aliquots of human platelet-rich plasma $(1.24 \times 107$ cells $)$ were incubated at $37^{\circ} \mathrm{C}$ for 3 minutes in $2 \mathrm{ml}$ of Krebs bicarbonate buffer, $\mathrm{pH}$ 7.4, containing $10 \mathrm{mmol} / \mathrm{L}$ glucose, $0.1 \mathrm{mmol} / \mathrm{L}$ iproniazid, $1 \mathrm{mmol} / \mathrm{L}$ ascorbic acid, $0.17 \mathrm{mmol} / \mathrm{L}$ EDTA, $50 \mathrm{nmol} / \mathrm{L}\left[{ }^{3} \mathrm{H}\right] 5$ $\mathrm{HT}$, and various concentrations of drug. Active 5-HT uptake was determined by subtracting the nonspecific uptake at $4^{\circ} \mathrm{C}$ Other conditions were as described in Materials and Methods. 
Table 3. Inhibition of 5-HT Uptake in Hypothalamus Homogenates Ex Vivo After an Intraperitoneal or Subcutaneous Administration of the Enantiomers of Norfluoxetine in Rats

\begin{tabular}{|c|c|c|c|}
\hline \multirow{2}{*}{$\begin{array}{c}\text { Dose } \\
\mathrm{mg} / \mathbf{k g}(\mu \mathrm{mol} / \mathbf{k g})\end{array}$} & \multirow[b]{2}{*}{ Route } & \multicolumn{2}{|c|}{ 5-HT Uptake, p mol/mg protein } \\
\hline & & $R$-Norfluoxetine & S-Norfluoxetine \\
\hline 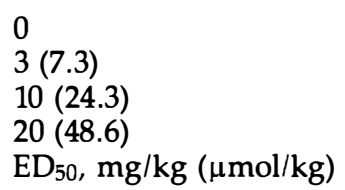 & $\begin{array}{l}\text { IP } \\
\text { IP } \\
\text { IP } \\
\text { IP }\end{array}$ & $\begin{array}{l}4.70 \pm 0.08 \\
4.08 \pm 0.13^{\#} \\
3.50 \pm 0.09^{\star} \\
2.97 \pm 0.07^{\star} \\
>20(48.6)\end{array}$ & $\begin{array}{l}5.00 \pm 0.29 \\
2.48 \pm 0.11^{\star} \\
1.47 \pm 0.14^{\star} \\
1.30 \pm 0.11^{\star} \\
3(7.3)\end{array}$ \\
\hline $\begin{array}{l}0 \\
3(7.3) \\
10(24.3) \\
20(48.6) \\
\mathrm{ED}_{50}, \mathrm{mg} / \mathrm{kg}(\mu \mathrm{mol} / \mathrm{kg})\end{array}$ & $\begin{array}{l}\text { SC } \\
\text { SC } \\
\text { SC } \\
\text { SC }\end{array}$ & $\begin{array}{l}3.29 \pm 0.17 \\
3.00 \pm 0.21 \\
2.58 \pm 0.20^{\dagger} \\
2.20 \pm 0.11^{\star} \\
>20(48.6)\end{array}$ & $\begin{array}{l}2.89 \pm 0.19 \\
1.81 \pm 0.28^{\#} \\
0.85 \pm 0.10^{\star} \\
0.37 \pm 0.04^{\star} \\
4.7(11.4)\end{array}$ \\
\hline
\end{tabular}

Groups of five rats were treated with either saline or an enantiomer of norfluoxetine at dose and route of administration indicated for an hour before killing. Hypothalamus was dissected and homogenized in $0.32 \mathrm{~mol} / \mathrm{L}$ sucrose. Aliquots of the homogenate in triplicate samples were incubated for uptake of 5-HT as described in Materials and Methods. Significant difference from control is indicated $\left({ }^{*} p<.001 ;{ }^{\#} p<.005 ;{ }^{\dagger} p<.05\right)$.

Ent (Figure 5). As observed in previous experiments (Table 4), S-norfluoxetine treatment did not change SHT levels in hypothalamus during the entire time ause of study (results not shown). A similar duration ddecrease of 5-HT uptake occurred following administation of S-norfluoxetine at $10 \mathrm{mg} / \mathrm{kg} \mathrm{SC}$, but 5 -HT upthe had returned to control levels by 48 hours after treatment (Table 5).

By means of radioligand-binding techniques, the mo enantiomers of norfluoxetine were found to interat with receptors of transmitters only an micromolar aigher concentrations, including subtypes of 5-HT meptors (1A, 1B, 1D, 2, and 3); adrenergic alpha1-, sphaz-, and beta-receptors; dopaminergic $\mathrm{D}_{1}$ and $\mathrm{D}_{2}$ reseptors; muscarinic acetylcholine receptors; and histamine $\mathrm{H} 1$ receptor (Table 6). Consistent with the findings on the enantiomers of fluoxetine (Wong et al. 1991b), $R$-norfluoxetine inhibited $\left[{ }^{3} \mathrm{H}\right]$ mesulergine binding to $5-\mathrm{HT}_{1 \mathrm{C}}$ sites in membranes of bovine choroid plexus with a $\mathrm{K}_{\mathrm{i}}$ of $0.18 \pm \mu \mathrm{mol} / \mathrm{kg}$, whereas $S$-norfluoxetine was much weaker, with a $\mathrm{K}_{\mathrm{i}}$ of $3.5 \mu \mathrm{mol} / \mathrm{kg}$ (Table 6).

\section{DISCUSSION}

Contrary to the equipotency of $R$ - and $S$-fluoxetine as inhibitors of 5-HT uptake (Wong et al. 1985, 1990), $S$-norfluoxetine is consistently more effective than $R$-norfluoxetine as an inhibitor of 5-HT uptake in synaptosomal preparations and human platelets in vitro. Indeed, $S$-norfluoxetine exhibited 20 times greater affinity than $R$-norfluoxetine for the 5-HT uptake sites

Table 4. Effect of S-Norfluoxetine Administered Orally on Uptake of 5-HT and NE in Hypothalamus Homogenates and Levels of Indole Metabolites in Cerebral Cortex

\begin{tabular}{|c|c|c|c|c|}
\hline \multirow{2}{*}{$\begin{array}{c}\text { S-Norfluoxetine } \\
\mathrm{mg} / \mathrm{kg}(\mu \mathrm{mol} / \mathrm{kg}) \text { po }\end{array}$} & \multicolumn{2}{|c|}{$\begin{array}{l}\text { Monoamine Uptake } \\
\text { (p mol/mg protein) }\end{array}$} & \multicolumn{2}{|c|}{$\begin{array}{l}\text { Metabolite Level } \\
\text { (nmol/g tissue }^{a} \text { ) }\end{array}$} \\
\hline & 5-HT & NE & 5-HT & 5-HIAA \\
\hline $\begin{array}{l}\text { Control } \\
3(7.3) \\
10(24.3) \\
20(48.6)\end{array}$ & $\begin{array}{l}5.5 \pm 0.4 \\
3.9 \pm 0.3^{\star} \\
2.5 \pm 0.4^{\star} \\
1.7 \pm 0.2^{\star}\end{array}$ & $\begin{array}{l}4.5 \pm 0.3 \\
4.6 \pm 0.3 \\
4.6 \pm 0.4 \\
4.6 \pm 0.3\end{array}$ & $\begin{array}{l}2.16 \pm 0.05 \\
2.14 \pm 0.05 \\
2.41 \pm 0.23 \\
2.19 \pm 0.10\end{array}$ & $\begin{array}{l}2.30 \pm 0.06 \\
2.24 \pm 0.04 \\
2.12 \pm 0.06 \\
1.96 \pm 0.05^{\#}\end{array}$ \\
\hline
\end{tabular}

Groups of five rats were treated with saline or $S$-norfluoxetine at the indicated doses and killed an hour later. Hypothalamus and cerebral cortex were dissected. Hypothalamus was homogenized in $0.32 \mathrm{~mol} / \mathrm{L}$ sucrose and used for measurement of 5-HT and NE uptake. Cerebral cortices were immediately frozen for subsequent measurement of indole metabolites. Other conditions were those described in Materials and Methods.

${ }^{a}$ Tissue weight was expressed in gram of wet weight.

Significant difference from control is indicated $\left({ }^{*} p<.025 ;{ }^{*} p<.002\right)$. 


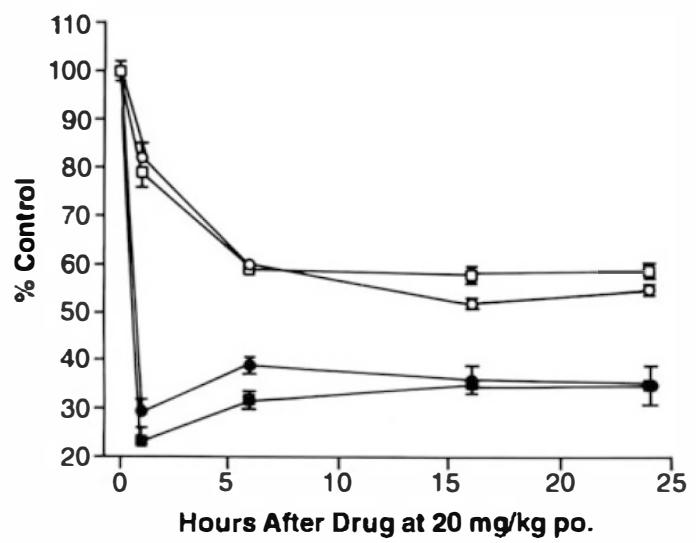

Figure 5. Duration of inhibition of 5-HT uptake in homogenates of cerebral cortex and lowering of 5-HIAA in hypothalamus of rats treated with fluoxetine or $S$-norfluoxetine in vivo. Groups of five rats were treated with fluoxetine (circles) or $S$-norfluoxetine (squares) at $20 \mathrm{mg} / \mathrm{kg}$ po and were killed by decapitation at the time intervals specified. A separate group of rats was treated with saline as control. The brain was removed, and the hypothalamus and cerebral cortex were dissected. Uptake of 5-HT in cortical homogenates (open symbols) and 5-HIAA levels in the hypothalamus (filled symbols) was measured as described in Materials and Methods. The drug-treated groups were significantly different from control groups $(p<.001)$.

labeled by $\left[{ }^{3} \mathrm{H}\right]$ paroxetine, and fluoxetine and its $R$ and $S$ enantiomers displaced $\left[{ }^{3} \mathrm{H}\right]$ paroxetine binding with equal affinities, as shown previously, using $\left[{ }^{3} \mathrm{H}\right]$ fluoxetine as radioligand binding to $5-\mathrm{HT}$ uptake sites (Wong et al. 1985). In fact, the $\mathrm{pK}_{\mathrm{i}}$ values of $S$-norfluoxetine are higher than the $\mathrm{pK}_{\mathrm{i}}$ value of $S$-fluoxetine as an inhibitor of $\left[{ }^{3} \mathrm{H}\right]$ paroxetine binding $(p<.01)$ in cortical preparations, suggesting that $\mathrm{N}$-demethylation of $S$-fluoxetine appears to increase intrinsic affinity for the 5-HT uptake carrier.

Table 5. Duration of Decrease on Uptake of 5-HT in Homogenates of Hypothalamus after Subcutaneous Administration of $S$-Norfluoxetine in Rats

\begin{tabular}{lcc}
\hline $\begin{array}{l}\text { Duration } \\
\text { (Hour) }\end{array}$ & $\begin{array}{c}\text { 5-HT Uptake } \\
\text { (pmol/mg protein) }\end{array}$ & $\begin{array}{c}\text { Percent of Control } \\
\text { (pmol/mg protein) }\end{array}$ \\
\hline 0 & $3.27 \pm 0.15$ & 100 \\
$1 / 2$ & $1.29 \pm 0.29^{\star}$ & 39.5 \\
1 & $1.03 \pm 0.07^{\star}$ & 31.5 \\
6 & $0.95 \pm 0.05^{\star}$ & 29.1 \\
24 & $2.73 \pm 0.22$ & 83.5 \\
48 & $3.24 \pm 0.15$ & 99.1 \\
\hline
\end{tabular}

Groups of four rats were treated with $S$-norfluoxetine at $10 \mathrm{mg} / \mathrm{kg}$ $(24.3 \mu \mathrm{mol} / \mathrm{kg}) \mathrm{SC}$ and were killed at the times indicated. A group of eight rats was treated with saline as a control group. Hypothalamus was dissected and homogenized in $0.32 \mathrm{~mol} / \mathrm{L}$ sucrose. Aliquots of the homogenate in duplicate samples were incubated for 5-HT uptake as described under Materials and Methods. Significant difference from control values is indicated $\left({ }^{\star} p<.001\right)$.
Table 6. Inhibition of Radioligand Binding to Receptors of Neurotransmitters by Enantiomers of Norfluoxetine

\begin{tabular}{|c|c|c|}
\hline Receptor & $\begin{array}{c}R \text {-Norfluoxetine } \\
\text { (K } \mathrm{K}_{\mathrm{i} \mu \mathrm{mol} / \mathrm{kg})}\end{array}$ & $\begin{array}{r}\text { S-Norfluoxetin } \\
\left(\mathbf{K}_{\mathbf{i}} \mu \mathrm{mol} / \mathbf{k g}_{\mathrm{g}}\right)\end{array}$ \\
\hline $5-\mathrm{HT}_{1 \mathrm{~A}}$ & $>10$ & $>10$ \\
\hline $5-\mathrm{HT}_{1 \mathrm{~B}}$ & $12.6 ; 7.1$ & $10.3 \pm 2.4$ \\
\hline $5-\mathrm{HT}_{1 \mathrm{C}}$ & $0.18 \pm 0.03$ & $3.5 \pm 0.5$ \\
\hline $5-\mathrm{HT}_{1 \mathrm{D}}$ & $57.5 \pm 13.5$ & $48.5 \pm 9.1$ \\
\hline $5-\mathrm{HT}_{2}$ & $0.57 \pm 0.03$ & $3.8 \pm 0.7$ \\
\hline $5-\mathrm{HT}_{3}$ & $3.1 ; 4.9$ & $>10$ \\
\hline Alpha-1-adrenergic & $>10$ & $>10$ \\
\hline Alpha-2-adrenergic & $>10$ & $>10$ \\
\hline Beta-adrenergic & $>10$ & $>10$ \\
\hline DA-1 & $>10$ & $>10$ \\
\hline $\mathrm{DA}-2$ & $>10$ & $>10$ \\
\hline Muscarinic-Ach & 2.9 & 2.8 \\
\hline Histamine-H1 & 3 & 2.5 \\
\hline
\end{tabular}

$\mathrm{K}_{\mathrm{i}}$ in mean $\pm \mathrm{SE}$ were calculated from $\mathrm{IC}_{50}$ values of at least three separate determinations. otherwise, values are shown as obtained from each determination.

Fluoxetine and norfluoxetine, as reported previously (Wong et al. 1975, 1990), and their respective enantiomers as demonstrated in the present study, are weak inhibitors of NE uptake. Using $\left[{ }^{3} \mathrm{H}\right]$ tomoxetine as a radioligand of NE uptake carrier(Wong et al. 1991a), we further show that norfluoxetine and its enantiomers are indeed weaker ligands for the NE uptake carrier. Calculating the ratios of $\mathrm{K}_{\mathrm{i}}$ inhibiting $\left[{ }^{3} \mathrm{H}\right.$ ] tomoxetine binding to $\mathrm{K}_{\mathrm{i}}$ inhibiting $\left[{ }^{3} \mathrm{H}\right]$ paroxetine binding, the values for fluoxetine, $R$-fluoxetine, $S$-fluoxetine, norfluoxetine, $R$-norfluoxetine, and $S$-norfluoxetine (Table 2) are 33, 20, 219, 697, 58, and 1317, respectively. In agreement with the inhibition of 5-HT and NE uptake, inhibition of direct radioligand binding to the respective uptake sites shows a minimum of 20 -fold greater affinity of $R$-fluoxetine for 5-HT than for NE uptake sites, whereas the selectivity of $S$-fluoxetine was 21 times higher, with a ratio of 219. Unexpectedly, $\mathrm{N}$-demethylation of $S$-fluoxetine to $S$-norfluoxetine confers an even greater selectivity for the 5-HT uptake sites over NE uptake sites, with a $K_{i}$ ratio of 1317. Even though $R$-norfluoxetine has one-eighth the affinity of $R$-fluoxetine for the $\left[{ }^{3} \mathrm{H}\right]$ paroxetine-labeled $5-\mathrm{HT}$ uptake site, it also has one-third the affinity of the parent drug for the $\left[{ }^{3} \mathrm{H}\right]$ tomoxetine-labeled NE uptake.

The present study demonstrates that $S$-norfluoxe tine is as potent as $S$-fluoxetine in inhibiting 5-HT uptake ex vivo (Wong et al. 1985). The closed $\mathrm{ED}_{50}$ values of $S$-norfluoxetine ranged from 3 to $9 \mathrm{mg} / \mathrm{kg}$ after intraperitoneal, subcutaneous, and oral routes of administration, suggesting excellent bioavailability and ready penetration into the brain. Consistent with the in vitro findings, $R$-norfluoxetine was relatively inactive as a 5-HT uptake inhibitor ex vivo with $\mathrm{ED}_{50}$ doses exceeding $20 \mathrm{mg} / \mathrm{kg}$. In vivo, fluoxetine and norfluoxetine 
$\varpi_{\mathrm{mg}} / \mathrm{kg}$ IP, more than twice the $\mathrm{ED}_{50}$ inhibiting 5-HT uptake ex vivo, failed to inhibit the accumulation of rafioactive NE in rat heart, whereas the tricyclic antidepressant drugs imipramine, desipramine, clomipraane, and chlorodesipramine at $5 \mathrm{mg} / \mathrm{kg}$ IP nearly aximally inhibited accumulation of $\mathrm{NE}$ radioactivity in heart (Wong et al. 1975).

The duration of 5-HT uptake inhibition was longer ther an administration of $S$-fluoxetine than $R$-fluoxetime (Wong et al. 1985). Both enantiomers are readily metabolized to form norfluoxetine (Potts et al. 1989; fuller et al. 1991; Potts and Parli 1992). The loss of inWitory effects beginning 5 hours after $R$-fluoxetine admistration can be explained by the generation of a reltively inactive metabolite, $R$-norfluoxetine, since both R-or $S$-norfluoxetine reached similar peak levels in brain tween 4 and 8 hours after administration of the coresponding enantiomer of fluoxetine (Fuller et al. 1990). On the other hand, the $\mathrm{N}$-demethylation of $S$-fluoxeine leads to an equally active and enduring metaboIn S-norfluoxetine, which was responsible for the mg-lasting inhibition of 5-HT uptake after treatment vith S-fluoxetine (Wong et al. 1985).

The $\mathrm{K}_{\mathrm{i}}$ ratios of $S$-fluoxetine (219) and $S$-norfluoxaine (1317) are 11 and 22 times higher than the $K_{i}$ cios of $R$-fluoxetine (20 and $R$-norfluoxetine (58), presenting a broad range of selectivity for the uptake ciers of 5-HT over those of NE. Despite having a low dectivity ratio of 20 and the submicromolar affinity of \&fuoxetine for NE uptake sites, administration of raanic fluoxetine to rats in vivo at doses up to 13 times - ED $_{50}(3.8 \mathrm{mg} / \mathrm{kg}$ i.p.) for inhibition of 5-HT in vivo tod to inhibit NE uptake in brain and in heart (Wong ad. 1975; Wong and Bymaster 1976). Higher doses were rarely used and would be considered unnecesyy. Since the enantiomers of the parent drug and the methylated metabolite should bear comparable physid and chemical properties, their tissue distribution snost likely to be similar. Comparable brain levels of wenantiomers of fluoxetine and norfluoxetine were deed achievable after a single dose of racemic fluoxein in rat (Potts and Parli 1992). Thus, a 5-HT uptake itbitor, having a selectivity ratio of 20 like $R$-fluoxeine, appears to provide adequate selectivity in vivo tomodinhibiting 5-HT uptake without inhibiting NE upte. In a recentclinical study, four individuals receiving memic fluoxetine daily for 45 days showed nearly a butold higher rate of clearance for $R$-fluoxetine comped to $S$-fluoxetine (R. Bergstrom, personal commuintion). As a result, one can expect that $S$-fluoxetine mumulates to higher concentrations than $R$-fluoxetine dconsequently ensures selectivity toward inhibiting क्षा uptake in humans.

Besides fluoxetine and the tertiary amine containgricyclic antidepressant drugs, including imipramine ad domipramine (Wong et al. 1975, Hyttel and Lar- sen 1985), $\mathrm{N}$-demethylation is also involved in the metabolism of other selective inhibitors of 5-HT uptake. Sertraline, a secondary amine, inhibited $50 \%$ of $5-\mathrm{HT}$ uptake with a concentration of $58 \mathrm{nmol} / \mathrm{kg}\left(\mathrm{IC}_{50}\right)$ and $\mathrm{NE}$ uptake with an $\mathrm{IC}_{50}$ of $1200 \mathrm{nmol} / \mathrm{kg}$, whereas the $\mathrm{N}$-demethylated metabolite, CP 62,508 , inhibited 5-HT and NE uptake with $\mathrm{IC}_{50}$ s of 450 and $4600 \mathrm{nmol} / \mathrm{kg}$, respectively (Koe et al. 1983). Thus, the ratio of $\mathrm{IC}_{50}$ inhibiting NE uptake to the $\mathrm{IC}_{50}$ inhibiting 5-HT uptake was reduced from 20 for sertraline to 10 for the desmethyl metabolite of sertraline. In ex vivo studies, sertraline was shown to be a selective inhibitor of 5-HT uptake without significantinhibition of NE uptake (Koe et al. 1983).

Citalopram, a tertiary amine, and its $\mathrm{N}$-demethylated metabolites desmethylcitalopram and didesmethylcitalopram inhibited 5-HT uptake with $\mathrm{IC}_{50}$ s of $1.8,7.4$ and $24 \mathrm{nmol} / \mathrm{kg}$, respectively, and were 4889 , 105 , and 63 times, respectively, less potent as inhibitors of NE uptake (Hyttel and Larsen, 1985). At twice the $\mathrm{ED}_{50}$ dose inhibiting 5-HT uptake ex vivo, citalopram at $10 \mathrm{mg} / \mathrm{kg}$ IP did not reduce NE uptake in midbrain synaptosomes of drug-treated rats (Maitre et al. 1980).

Like other inhibitors of 5-HT uptake, including fluoxetine, oral administration of $S$-norfluoxetine at 20 $\mathrm{mg} / \mathrm{kg}$ caused a decrease of 5-HIAA levels in hypothalamus and cerebral cortex, whereas 5-HT levels in these brain areas were essentially unchanged. It is believed that the decrease in 5-HIAA levels reflects a decrease of 5-HT turnover, a consequence of greater synaptic availability of 5-HT when presynaptic 5-HT uptake is inhibited.

The two enantiomers of norfluoxetine are similar to fluoxetine (Wong et al. 1983) and its two enantiomers (Wong et al. 1985), and have little affinity for receptors of neurotransmitters, including 5-HT, NE, DA, acetylcholine, and histamine. The relatively low affinity of the norfluoxetine enantiomers for receptors of acetylcholine (muscarinic class) and histamine is consistent with the low incidence of anticholinergic and antihistaminergic side-effect profiles of fluoxetine and norfluoxetine (Feighner 1983; Beasley et al. 1990). Among subtypes of 5-HT receptors, $R$ enantiomers of norfluoxetine (present study) and fluoxetine (Wong et al. 1991) exhibit submicromolar affinity for $5-\mathrm{HT}_{1 \mathrm{C}}$ receptors in membranes of bovine choroid plexus; however, it should be noted that the affinity of the two $R$ enantiomers for the 5-HT uptake site is two orders of magnitude higher. Nevertheless, the pharmacologic effects of the two $R$ enantiomers on $5-\mathrm{HT}_{1}$ c receptors are an important area for further investigation.

\section{ACKNOWLEDGMENT}

We thank Mrs. Joan Hager for preparation of the manuscript. 


\section{REFERENCES}

Beasley CM, Bosomworth JC, Wernicke JF (1990): Fluoxetine: Relationship among dose, response, adverse events, and plasma concentrations in the treatment of depression. Psychopharmacol Bull 26:18-24

Cheng YC, Prusoff WH (1973): Relationship between the inhibition constant $(\mathrm{Ki})$ and the concentration of inhibitor which causes 50 percent inhibition (I50) of an enzymatic reaction. Biochem Pharmacol 22:3099-3108

Feighner JP (1983): The new generation of antidepressants. J Clin Psychiatry 44:49-55

Fuller RW, Snoddy HD, Perry KW, Bymaster FP, Wong DT (1978): Importance of duration of drug action in the antagonism of p-chloroamphetamine depletion of brain serotonin-comparison of fluoxetine and chlorimipramine. Biochem Pharmacol 27:193-198

Fuller RW, Wong DT, Robertson DW (1991): Fluoxetine, a selective inhibitor of serotonin uptake. Medicinal Res Rev 11:17-34

Horng JS, Wong DT (1976): Effects of serotonin uptake inhibitor, Lilly 110140 , on transport of serotonin in rat and human blood platelets. Biochem Pharmacol 25:865-867

Hoyer D, Engel G, Kalkman HO (1985): Molecular pharmacology of 5-HT1 and 5-HT2 recognition sites in rat and pig brain membranes: Radioligand binding studies with $\left[{ }^{3} \mathrm{H}\right] 5-\mathrm{HT},\left[{ }^{3} \mathrm{H}\right] 8-\mathrm{OHDPAT},(-)\left[{ }^{125} \mathrm{I}\right]$ iodocyanopindolol, $\left[{ }^{3} \mathrm{H}\right]$ mesulergine and $\left[{ }^{3} \mathrm{H}\right]$ ketanserin. Eur J Pharmacol 118:13-23

Hyttel J, Larsen J-J (1985): Serotonin selective antidepressants. Acta Pharmacol Toxicol 56 (Suppl):146-153

Koe BK, Weissman A, Welch WM, Browne RG (1983): Sertraline, 1S,4S-N-methyl-4-(3,4-dichlorophenyl)-1,2,3,4tetrahydro-1-naphthylamine, a new uptake inhibitor with selectivity for serotonin. J Pharmacol Exp Ther 226: 686-700

Lemberger L, Rowe H, Carmichael R, Crabtree R, Horng JS, Wong DT (1978): Fluoxetine, a selective serotonin uptake inhibitor. Clin Pharmacol Ther 23:421-429

Maitre L, Moser P, BaumannPA, Waldmeier PC (1980): Amine uptake inhibitors: Criteria of selectivity. Acta Psychiatr Scand 61 (Suppl 280):97-110

Marcusson JO, Bergstrom M, Eriksson K, Ross SB (1988): Characterization of $\left[{ }^{3} \mathrm{H}\right]$ paroxetine binding in rat brain. J Neurochem 50:1783-1790

Parli CJ, Hicks J (1974): In vivo demethylation of Lilly 110140 : 3-(p-trifluoromethylphenoxy)-N-methyl-3-phenylpropylamine to an active metabolite-Lilly 103947. Fed Proc 33:560 (Abstract)
Potts BD, Wethington CR, Parli CJ (1989): Development of an indirect HPLC enantioseparation technique for the analysis of plasma concentrations of $R$-and $S$-fluoxetine in animals dosed with fluoxetine. Pharmacologist 31:153 (Abstract)

Potts BD, Parli CJ (1992): Analysis of the enantiomers of fluoxetine and norfluoxetine in plasma and tissue using diural derivatization and normal-phase liquid chromatography. J Liq Chromatogr 15:665-681

Robertson DW, Krushinski JH, Fuller RW, Leander JD(1988): Absolute configurations and pharmacological activities of the optical isomers of fluoxetine, a selective serotoninuptake inhibitor. J Med Chem 31:1412-1417

Wong DT, Bymaster FP (1976): The comparison of fluoxetine and nisoxetine with tricyclic antidepressants in blocking the neurotoxicity of p-chloroamphetamine and 6-hydroxydopamine in the rat brain. Res Commun Chem Pathol Pharmacol 15:221-231

Wong DT, Horng JS, Bymaster FP, Hauser KL, Molloy BB (1974): A selective inhibitor of serotonin uptake: Lilly 110140, 3-(p-trifluoromethylphenoxy)-N-methyl-3-phenypropylamine. Life Sci 15:471-479

Wong DT, Bymaster FP, Horng JS, Molloy BB (1975): A new selective inhibitor for uptake of serotonin into synapto somes of rat brain: 3-(p-Trifluoromethylphenoxy). $\mathrm{N}$. methyl-3-phenylpropylamine. J Pharmacol Exp Ther 193:804-811

Wong DT, Bymaster FP, Reid LR, Threlkeld PG (1983): Fluoxetine and two other serotonin uptake inhibitors without affinity for neuronal receptors. Biochem Pharmacol 32: 1287-1293

Wong DT, Bymaster FP, Reid LR, Fuller RW, Perry KW (1985): Inhibition of serotonin uptake by optical isomers of fluoxetine. Drug Dev Res 6:397-403

Wong DT, Robertson DW, Reid LR (1989): Specific [ [ $\left.{ }^{3} \mathrm{H}\right]$ LY278584 binding to 5- $\mathrm{HT}_{3}$ recognition sites in rat cerebral cortex. Eur J Pharmacol 166:107-110

Wong DT, Fuller RW, Robertson DW (1990): Fluoxetine and its two enantiomers as selective serotonin uptake inhibitors. Acta Pharmacol Nord 2:171-180

Wong DT, Robertson DW, Gackenheimer SL, Reid LR, Schober DA, Thompson DC, Gehlert DR (1991a): [ $\left[{ }^{3} \mathrm{H}\right]$. Tomoxetine: A highly selective, enantiomerically pure radioligand for norepinephrine uptake sites in brain. Abst 21st Annual Meeting Soc Neurosci

Wong DT, Threlkeld PG, Robertson DW (1991b): Affinities of fluoxetine, its enantiomers and other inhibitors of serotonin uptake for subtypes of serotonin receptors. Nev. ropsychopharmacology 5:43-47. 